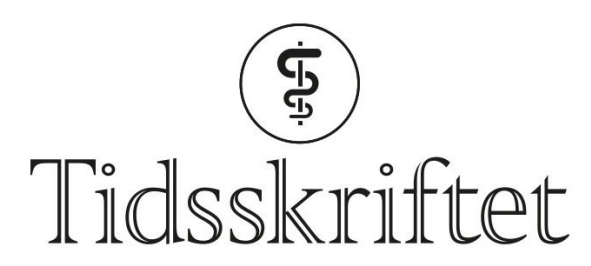

DEN NORSKE LEGEFORENING

\title{
Tvangsinnleggelse for rusbehandling?
}

KRONIKK

\section{ØISTEIN KRISTENSEN}

E-post: oisteinkristensen@hotmail.com

$\emptyset$ istein Kristensen (f. 1945) er spesialist i psykiatri og i rus- og avhengighetsmedisin, overlege og seniorforsker ved Avdeling for rus- og avhengighetsbehandling, Sørlandet sykehus. Forfatter har fylt ut ICMJE-skjemaet og oppgir ingen interessekonflikter.

\section{ANNE OPSAL}

Anne Opsal (f. 1969) er sykepleier, ph.d., førsteamanuensis ved Institutt for helse- og sykepleievitenskap, Universitetet i Agder, og forskningsveileder ved Avdeling for rus- og avhengighetsbehandling, Sørlandet sykehus.

Forfatter har fylt ut ICMJE-skjemaet og oppgir ingen interessekonflikter.

\section{THOMAS CLAUSEN}

Thomas Clausen (f. 1972) er professor dr.med. ved Senter for rus- og avhengighetsforskning, Universitetet i Oslo, og forskningsveileder ved Avdeling for rus- og avhengighetsbehandling, Sørlandet sykehus.

Forfatter har fylt ut ICMJE-skjemaet og oppgir ingen interessekonflikter.

Noen rusmiddelavhengige er så nedkjørte at de vanskelig kan ta standpunkt til innleggelse eller medvirke til å komme i behandling. I dag har ikke leger mulighet til å tvangsinnlegge disse pasientene. Det kan imidlertid kommunens omsorgstjeneste/Nav.

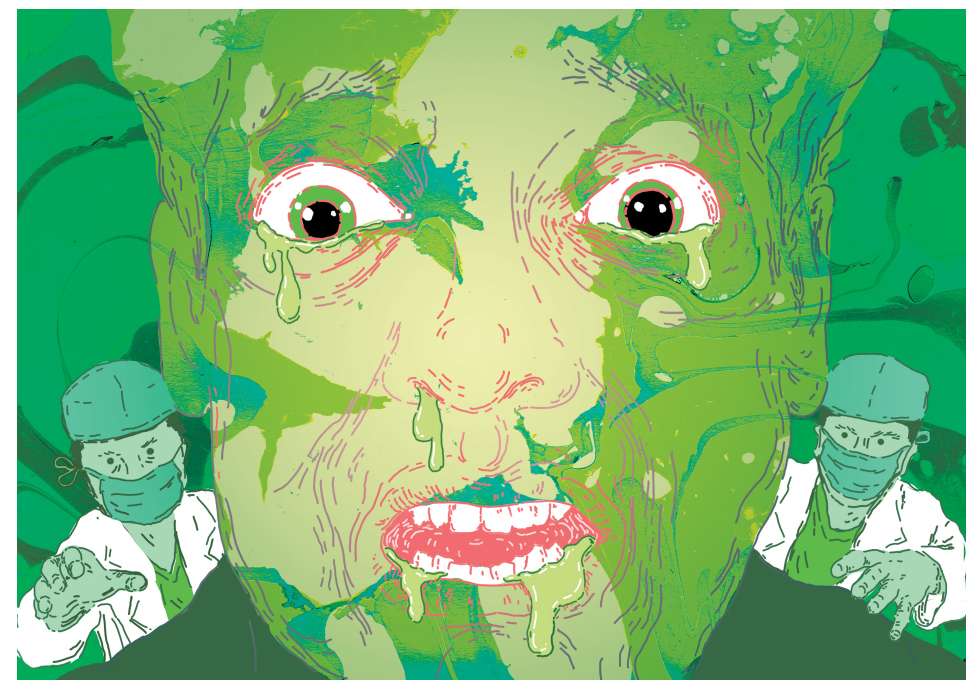

Illustrasjon: Sylvia Stølan

Det er nå dokumentert at tvangsinnleggelse har positiv effekt for noen rusmiddelavhengige. En norsk studie fra perioden 2013-17 (1-5), der man unders $\varnothing \mathrm{kte}$ hvordan det gikk med tvangsinnlagte med rusbrukslidelser innlagt etter § $10.2 \mathrm{i}$ lov om 
kommunale helse- og omsorgstjenester m.m. (helse- og omsorgstjenesteloven) seks måneder etter utskrivning, viste at innleggelse i tverrfaglig spesialisert rusbehandling (TSB) ga bedre rusmestring og høyere livskvalitet (1-4). Hovedtendensen var at forbedringene i rusmestring var noe mindre hos de tvangsinnlagte enn hos de frivillig innlagte. En firedel av de tvangsinnlagte var blitt avholdende, andre hadde redusert bruksfrekvensen.

Alternativet til tvangsinnleggelse er som oftest ingen behandling - og med det gradvis forverring. Hvis man tar dette i betraktning, må resultatene for tvangsgruppen vurderes som rimelig gode (3). Seks måneder etter utskrivning hadde $58 \%$ av samtlige en statistisk signifikant bedret livskvalitet, og hos $26 \%$ var det en betydelig bedring. Ingen var blitt dårligere. Det var ingen forskjell mellom gruppene frivillig innlagte og tvangsinnlagte (2). Tre av fire pasienter i studien var i ettertid positive til at tvang ble iverksatt (5).

En svensk kunnskapsoversikt med oppfølgingsstudier fra tre tidsperioder (1982-87, 1988-94 og 1995-2000) konkluderte med at gjennomsnittlig andel med redusert rusmiddelbruk ett år etter utskrivning fra tvangsbehandling var $30 \%(6)$. Andelen helt rusfrie var $9 \%$. Oversikten avdekket en positiv tendens. I siste tidsperiode var det $38 \%$ som hadde redusert rusmiddelbruken, og $14 \%$ var helt rusmiddelfrie.

I Sverige blir om lag goo pasienter tvangsinnlagt årlig etter sosiallovgivningen der. I Norge er det ytterst få, ca. 150 per år, som tvangsinnlegges i tverrfaglig spesialisert rusbehandling. Tallet har vært stabilt de siste årene (7). Dette utgjorde kun 1,7\% av pasientene innlagt i døgnbehandling i tverrfaglig spesialisert rusbehandling i 2015.

Ettersom alkohol er regnet for å være en av de viktigste årsakene til dårlig helse (8) og 26o liv går tapt grunnet narkotikabruk hvert år (9), kan det stilles spørsmål ved om tvangsparagrafen benyttes ofte nok. Mange som burde vært innlagt, motsetter seg behandling. Det har vært ytret ønske om mer bruk av tvang for pasienter med livstruende ruslidelse, både politisk og fra de pårørendes organisasjoner (10).

\section{Lover for tvangsinnleggelse}

To lover åpner for tvangsinnleggelse av voksne i denne sammenheng, nemlig lov om etablering og gjennomføring av psykisk helsevern (psykisk helsevernloven) og lov om kommunale helse- og omsorgstjenester m.m. (helse- og omsorgstjenesteloven). Det kan være grunn til å se nærmere på dem $(\operatorname{tab} 1)(7,11)$.

\section{Tabell 1}

Tvangsbestemmelsene. Tallene er hentet fra ${ }^{1}$ Folkehelseinstituttet (7) og fra ${ }^{2}$ Norsk pasientregister (11)

\begin{tabular}{|lll|}
\hline & $\begin{array}{l}\text { Helse- og } \\
\text { omsorgstjenesteloven } \\
\text { \$ 10.2 Tvungent tilbakehold }\end{array}$ & $\begin{array}{l}\text { Psykisk helsevernloven } \\
\text { \$3.2 Tvungen observasjon } \\
\text { \$3.3 Tvungent psykisk } \\
\text { helsevern }\end{array}$ \\
\hline $\begin{array}{l}\text { Antall pasienter innlagt i } \\
2015\end{array}$ & $155^{1}$ & $5608^{2}$ \\
\hline Innleggende instans & $\begin{array}{l}\text { Kommunal omsorgtjeneste } \\
\text { (Nav) }\end{array}$ & Leger \\
\hline Avgjør innleggelse & $\begin{array}{l}\text { Fylkesnemnda (ledet av } \\
\text { jurist) }\end{array}$ & Vurdering av to leger \\
\hline Klageadgang & Fylkesmannen & Kontrollkommisjonen \\
\hline Formål med innleggelse & $\begin{array}{l}\text { Redde liv, hindre skade, } \\
\text { Motivere for rehabilitering }\end{array}$ & $\begin{array}{l}\text { Behandling av ikke- } \\
\text { samtykkekompetent pasient }\end{array}$ \\
\hline $\begin{array}{l}\text { Krav om vurdering av } \\
\text { samtykkekompetanse }\end{array}$ & Nei & Ja \\
\hline
\end{tabular}




\begin{tabular}{|lll|}
\hline & $\begin{array}{l}\text { Helse- og } \\
\text { omsorgstjenesteloven } \\
\mathbf{\$} \text { 10.2 Tvungent tilbakehold }\end{array}$ & $\begin{array}{l}\text { Psykisk helsevernloven } \\
\text { \$3.2 Tvungen observasjon } \\
\text { \$3.3 Tvungent psykisk } \\
\text { helsevern }\end{array}$ \\
\hline Betingelse & $\begin{array}{l}\text { Fare for fysisk og psykisk } \\
\text { helseskade på grunn av } \\
\text { omfattende og vedvarende } \\
\text { rusmisbruk }\end{array}$ & $\begin{array}{l}\text { Alvorlig psykisk lidelse } \\
\text { (psykose) }\end{array}$ \\
& $\begin{array}{l}\text { Tilbakeholdes maks } \\
\text { 3 måneder }\end{array}$ & $\begin{array}{l}\text { Tvungen observasjon 10 + } 10 \\
\text { dager } \\
\text { Lengden på oppholdet }\end{array}$ \\
& & $\begin{array}{l}\text { Tvungent psykisk helsevern } \\
\text { inntil 1 år, kan forlenges med } \\
\text { inntil 1 år om gangen }\end{array}$ \\
\hline
\end{tabular}

For leger og annet helsepersonell er bruk av tvang knyttet til håndteringen av personer med alvorlig psykisk sykdom. En betydelig andel av dem som legges inn etter loven om psykisk helsevern vil ha en komorbid ruslidelse. «En påstått overdreven bruk av innleggelse og behandling ved tvang har møtt til dels betydelig kritikk. Det helsepolitiske mantraet om å redusere tvangsbruken i psykiatrien ble støttet av offentligheten og fagfolk i feltet», skrev Geir W. Jacobsen på redaksjonell plass i Tidsskriftet (12).

\section{Legens rolle vanskeliggjort}

Fra 1.9.2017 fikk man i lov om etablering og gjennomføring av psykisk helsevern innført et nytt tilleggskriterium om manglende samtykkekompetanse, samtidig som behandlingskriteriet ble fjernet. Endringen gjør det betydelig vanskeligere å tvangsinnlegge en psykotisk pasient til behandling i institusjon dersom vedkommende vurderes som samtykkekompetent og motsetter seg innleggelse. Det gjelder også om dette vil føre til forverring av pasientens psykiske sykdom og til økt belastning på familie og pårørende (13). Dette vil også gjelde en pasient med komorbid ruslidelse. Legene har en viktig rolle i anvendelse av lov om etablering og gjennomføring av psykisk helsevern, men muligheten for tvangsinnleggelse etter denne loven er blitt betydelig trangere etter lovjusteringen.

Helse- og omsorgtjenesteloven gir åpning for tvangsinnleggelse av personer med primær og livstruende ruslidelse, men leger har ikke innleggelsesrett. Denne loven er også lite kjent blant leger. Kommunene, ved Nav, har enerett på utredning og innstilling overfor fylkesnemnda, som tar den endelige avgjørelsen om tvangsinnleggelse (10).

Prosessen før innleggelse er langdryg og omstendelig og holdningen blant personalet ofte ambivalent til bruk av tvang. Frem til nylig har lite kunnskap om effekt av tvangstiltaket bidratt til lav interesse for temaet. Hastevedtak kan gjøres av juristen i fylkesnemnda alene. Dette må ettergodkjennes av nemnda innen to uker for å være gyldig (10). Loven er moden for revisjon, slik at også leger kan medvirke både i fylkesnemnda og i innleggelsesprosessen.

Helsedirektoratet ga i 2016 ut både en forskrift om rettigheter og bruk av tvang under opphold i institusjon for behandling, omsorg og rehabilitering av personer med rusmiddelproblemer (14) og en veileder om tvangstiltak overfor personer med rusmiddelproblemer (15). Forutsetningen for bruk av tvang er at frivillige tiltak er forsøkt, at slike tiltak er avslått av pasienten eller at frivillige tiltak anses som åpenbart formålsløse. Skadevilkåret «fysiske og psykiske negative helsekonsekvenser» må være oppfylt og knyttet til misbruket. Dertil kommer et prognosekrav om at tiltaket anses å bidra til å hindre at pasienten får mer helseskader. De regionale helseforetakene må sørge for at det finnes tilstrekkelig med egnede institusjonsplasser.

Dagens lovtekst er en videreføring av sosialtjenesteloven fra 1992. På det tidspunktet var rusmiddellidelser i liten grad forstått som medisinsk problem og var hovedsakelig sosialtjenestens ansvarsområde. Mye har skjedd siden da. Tverrfaglig spesialisert behandling for rusmiddelavhengighet ble en del av spesialisthelsetjenesten i 2004 og rusog avhengighetsmedisin ble egen spesialitet i 2014. Og med innføring av 
legemiddelassistert rehabilitering (LAR) i 1998 fikk både fastleger og spesialister en mye tydeligere rolle i behandlingen av ruslidelser. Tiden vurderes derfor som overmoden for at lovteksten og logistikken endres og bedre reflekterer behandlingssystemet slik det ser ut i dag.

Et minimum av endring bør være at leger også kan gå direkte til fylkesnemnda, eventuelt tvangsinnlegge pasienter direkte for alvorlig ruslidelse, gitt at alvorlig rusmiddelavhengighet er et helseproblem. I dag er ingen leger representert i fylkesnemnda som gjør vedtak om tvangsinnleggelse. Beholdes fylkesnemndene, er styrket legekompetanse i nemnda nødvendig.

LITTERATUR:

1. Opsal A, Kristensen $\emptyset$, Larsen TK et al. Factors associated with involuntary admissions among patients with substance use disorders and comorbidity: a cross-sectional study. BMC Health Serv Res 2013; 13: 57. [PubMed][CrossRef]

2. Pasareanu AR, Opsal A, Vederhus JK et al. Quality of life improved following in-patient substance use disorder treatment. Health Qual Life Outcomes 2015; 13:35. [PubMed][CrossRef]

3. Pasareanu AR, Vederhus JK, Opsal A et al. Improved drug-use patterns at 6 months post-discharge from inpatient substance use disorder treatment: results from compulsorily and voluntarily admitted patients. BMC Health Serv Res 2016; 16: 291. [PubMed][CrossRef]

4. Pasareanu AR, Vederhus JK, Opsal A et al. Mental distress following inpatient substance use treatment, modified by substance use; comparing voluntary and compulsory admissions. BMC Health Serv Res 2017; 17: 5. [PubMed][CrossRef]

5. Vederhus JK. Tvangsinnleggelse av rusmiddelavhengige - noen etiske perspektiver. I: Leer-Salvesen P, Mæsel T, red. Makt og avmakt. Etiske perspektiver på feltet psykisk helse. Kristiansand: Portal Forlag, 2013: 242-60.

6. Gerdner A, Berglund M. Tvangvård vid missbruk - effekt och kvalitet. I: Larsson G, red. Missbruket, kunnskapen, vården - misbruksutredningens forskningsbilag. SOU 2011; 6: 653-770. Stockholm: Statens Offentliga Utredningar, 2011.

7. Skretting A, Bye EK, Vedøy TF et al. Rusmidler i Norge 2016. Oslo: Folkehelseinstituttet, 2016. https://www.fhi.no/publ/2017/rusmidler-i-norge-2016/(26.2.2018).

8. Global Strategy to reduce the harmful use of alcohol. Genève: WHO, 2010.

9. Narkotikautløste dødsfall i Norge i 2015. Oslo: Folkehelseinstituttet, 2016.

10. Lundeberg IR, Mjåland K, Søvig KH. Tvang i rusfeltet. Regelverk, praksis og erfaringer med tvang. Oslo: Gyldendal Juridisk, 2014.

11. Norsk pasientregister. https://helsedirektoratet.no/norsk-pasientregister-npr (26.2.2018).

12. Jacobsen GW. Den besværlige tvangen. Tidsskr Nor Legeforen 2017; 137: 22.

13. Lien L, Terjesen AG. Ny psykisk helsevernlov øker byrden for pårørende. Aftenposten 25.9.2017.

14. Forskrift om rettigheter og bruk av tvang under opphold i institusjon for behandling, omsorg og rehabilitering av personer med rusmiddelproblemer. FOR-2016-08-26-1003. https://lovdata.no/forskrift/2016-o8-26-1003 (12.12.2017).

15. Tvang overfor personer med rusmiddelproblemer. Veileder om tvangstiltak overfor personer med rusmiddelproblemer.

https://helsedirektoratet.no/retningslinjer/veileder-om-tvangstiltak-overfor-personer-med-rusmiddel problemer(12.12.2017).

Publisert: 12. april 2018. Tidsskr Nor Legeforen. DOI: 10.4045/tidsskr.17.1114

Mottatt 21.12.2017, første revisjon innsendt 6.2.2018, godkjent 26.2.2018.

(C) Tidsskrift for Den norske legeforening 2020. Lastet ned fra tidsskriftet.no 